\title{
Effects of Doinsenggitang on Melanin Synthesis and Gene Expression Inhibition in B16F10 Melanoma Cells
}

\author{
Ju-Young Hwang', Dong-Hee Kim', Hui-Jung Kim', Eun-Young Hwang', Tae-Soon Park', \\ Jin-Young Lee ${ }^{2}$ and Jun-Ho Son * \\ ${ }^{1}$ Korea Promotion Institute for Traditional Medicine Industry, Gyeongsan 712-260, Korea \\ ${ }^{2}$ Department of Herbal Cosmetic Science, Hoseo University, Chungnam 336-795, Korea
}

Received October 11, 2011 /Revised February 14, 2012 / Accepted February 16, 2012

This study involved observation of the inhibitory effect of $70 \% \mathrm{EtOH}$ and water extracts from Doinseunggitang on melanin synthesis, tyrosinase activity, and western blotting using B16F10 melanoma cells. Doinseunggitang extracts inhibited melanin synthesis and tyrosinase activity in a dependent manner. As a result, it was found that Doinseunggitang $70 \% \mathrm{EtOH}$ extracts inhibit melanin synthesis and tyrosinase activity, respectively, by $40 \%$ and $51 \%$. In addition, western blotting analysis showed that $70 \% \mathrm{EtOH}$ extracts inhibited tyrosinase, MITF, TRP-1, and TRP-2 expression. These results show that $70 \%$ ethanol extracts of Doinseunggitang could be developed as a skin whitening material in cosmetics.

Key words : Doinseunggitang, tyrosinase, microphthalmia transcription factor, tyrosinase related protein

\section{서 론}

사람의 피부색은 인종, 성별, 연령에 따라 다르지만 오늘날 사람들은 사회활동의 증가, 환경오염에 따른 오존층 파괴로 인하여 유해 자외선에 장기적으로 노출되고 있다. 피부가 자 외선에 과다 노출됨에 따라 피부 홍반과 흑화, 색소침착, 광 노화, 피부암등 피부 건강뿐만 아니라 미적 측면에서도 크게 영향을 받고 있다. 특히 색소 침착과 같은 피부 흑화는 피부에 존재하는 melanin 합성이 원인이 되는 것으로 알려져 있다 [6,31].

멜라닌(melanin)은 자연계에 널리 존재하는 생체 고분자 물 질로 인간의 피부 색깔을 결정짓는 색소로 알려져 있으며 자 외선이나 free radical 로부터 피부가 손상되는 것을 방지하는 역할을 담당하고 있다[19]. 이 색소는 멜라닌형성세포 내에 위 치하는 멜라노좀(melanosome)에 의해 만들어지며 형성된 멜 라닌은 각질형성세포로 이동하여 피부 상피층에 축적되어 색 소침착 현상이 나타난다[22]. 멜라닌 합성은 아미노산의 하나 인 tyrosine을 기질로 tyrosinase, tyrosinase related protein-1 (TRP-1), tyrosinase related protein-2 (TRP-2)에 의해 3,4-dihydroxyphenylalanine (DOPA)를 거쳐 DOPA quinone으로 전환되고 자동산화반응과 효소반응으로 $\mathrm{DOPA}$ chrome을 거 쳐 흑갈색의 공동합체인 멜라닌이 생성하게 된다[30]. 특히 tyrosinase 효소는 melanocyte에서 멜라닌 색소의 합성에서 주 요 핵심 효소로써 eumelanin과 pheomelanin의 합성에 절대

\footnotetext{
*Corresponding author Tel : +82-54-810-0320, Fax : +82-54-801-9896 E-mail : bio115@hanmail.net
}

적으로 필요한 것으로 알려져 있고 $[9,26,32,34]$, 최근에는 이와 같은 효소를 억제하여 멜라닌 합성 저해를 위한 연구가 활발 히 이루어지고 있다[28].

현재 알려진 미백원료로는 arbutin, kojic acid, ascorbic acid 등의 물질들이 대표적으로 사용되어 왔으나 이러한 물질 들은 불안정하여 분해나 착색, 이취, 효과의 불분명 및 안전성 문제 등으로 사용이 제한되고 있는 실정이다[36,5,35,38]. 이에 따라 세포에 영향을 미치지 않으며 melanin 합성을 감소시키 는 천연 미백제에 대한 연구가 활발히 진행 중이다. 천연소재 를 활용한 미백 관련 연구로는 참나물, 라벤더, 복분자 추출물 의 멜라닌 생합성 억제 효과[14,16,24] 등 연구가 있으며, 독활 기생탕, 서시옥용산 등의 복합제제를 이용한 미백효과를 연구 한 결과가 있다[25,27]. 이러한 연구들은 melanoma 세포의 tyrosinase 활성과 tyrosinase protein 발현을 억제하여 melanin 형성을 억제시킨다고 보고하였다.

도인승기탕(桃仁承氣湯)은 동의보감에서 기미, 미백, 여드 름에 효능이 있다고 기록되어 있으며 어혈을 풀게 하여 피부 가 거칠어진 사람에게 사용하는 천연약재의 복합처방으로 도 인, 감초, 대황, 계지, 망초 등 5 가지 한약재로 구성되어 있다 [15]. 특히 도인승기탕을 구성하는 주요 약재 중에서 도인은 복숭아씨로서 천연항산화제, 노화억제, 항암억제제로 오래 전 부터 여성의 질환과 퇴행성 질환 등에 사용되었으며 anti tumor promoter, 항 어혈 작용 등이 보고되어 있다[7,18,29]. 그 리고 감초는 tyrosinase 억제제로 작용하여 멜라닌 합성을 억 제하는 효과가 있어 kojic acid 보다 효능이 우수한 것으로 알 려져 있으므로[8], 도인승기탕의 미백효과에 영향을 미칠 것으 로 생각된다. 현재까지 도인승기탕이 어혈을 풀게 해주는 효 
능에 대한 연구결과는 나와있지만 미백에 관한 연구는 보고되 지 않았다.

따라서 본 연구에서는 B16F10 melanoma 세포를 배양한 후 도인승기탕 추출물을 처리하여 melanin 함량, tyrosinase 활성, western blot을 이용하여 MITF, tyrosinase, TRP-1, TRP-2 등의 단백질 발현을 통해 미백효과에 미치는 영향을 관찰하였다.

\section{재료 및 방법}

\section{시료 추출}

도인승기탕 제조에 필요한 구성약재는 휴먼허브(경북 경산 시)에서 구입하여 사용하였다. 시료는 대황 $30 \mathrm{~g}$, 계지 $20 \mathrm{~g}$, 도인 $100 \mathrm{~g}$, 망초 $20 \mathrm{~g}$, 감초 $100 \mathrm{~g}$ 을 혼합하여 열수 추출은 시료에 증류수를 1 배의 양을 가하여 $85^{\circ} \mathrm{C}$ 에서 3 시간 환류 낭 각 추출한 뒤 상등액과 침전물을 분리하여 3 회 반복 추출하였 다. 에탄올 추출물은 시료에 10 배 양의 $70 \%$ 에탄올을 첨가하 여 실온에서 24시간 동안 침지 추출한 후 상등액과 침전물을 분리하는 방법으로 3회 반복 추출하였다. 그리고 Whatman No. 1 여과지로 여과하고 농축하여 동결건조 후 냉장실에 보 관하면서 본 실험의 시료로 사용하였다.

\section{시약 및 기기}

세포배양을 위한 Dulbeco's modified eagle's medium (DMEM), fetal bovine serum (FBS), streptomycin penicillin, trypsin 250은 Gibco BRL Co. (Grand Island, NY, USA)로부터 구입하여 사용하였고, 3-[4,5-dimethyl-thiazol-2-yl]-2,5- diphenyl-tetrazoliumbromide (MTT), arbutin, L-3,4-dihydroxyphenylalanine (L-DOPA)는 Sigma Chemical Co. (St. Louis, USA)에서 구입하여 사용하였다. 1차 항체 인 tyrosinase, MITF, TRP-1, TRP-2와 2차 항체는 santa cruz (CA, USA)에서 구입하여 사용하였다. 실험에 사용한 기기는 ELISA reader (Tecan, Mönnedorf, Switzerland), rotary vacuum evaporator (Rikakikai Co., Tokyo, Japan), freeze drier (Ilsin, Gyonggi-do, Korea), centrifuge (Eppendorf, AG, Germany), microscope (Nikon, Tokyo, Japan), $\mathrm{CO}_{2}$ incubator (Hanbaek, Gyeonggi-do, Korea), haemacytometer (Marienfeld, Germany)를 사용하였다.

\section{세포 배양}

B16F10 melanoma cell은 ATCC (American Type Culture Collection)에서 분양 받아 사용하였으며, Michikaw 등 [23]의 방법에 따라 배양하였다. 세포에 $0.25 \%$ trypsin 용액을 희석 처리한 후 세포를 분리한 다음 $\mathrm{DMEM}$ 배지에 $10 \% \mathrm{FBS}$ 와 $1 \%$ penicillin/streptomycin $(100 \mathrm{U} / \mathrm{ml})$ 을 첨가하여 $37^{\circ} \mathrm{C}, 5 \%$ $\mathrm{CO}_{2}$ incubator에 적응시켜 배양하였다.

\section{$\mathrm{MTT}$ assay에 의한 세포 생존능력 측정}

세포 생존률 측정은 Carmichael 등[3]의 방법에 따라 측정 하였다. 세포를 96 well plate에 $0.6 \sim 0.8 \times 10^{3}$ cells/well이 되게 $180 \mu \mathrm{l}$ 분주하고, 시료를 농도 별로 조제하여 $20 \mu \mathrm{l}$ 첨가한 후 $37^{\circ} \mathrm{C}, 5 \% \mathrm{CO}_{2}$ incubator에서 48 시간 배양하였다. 배양 후 5 $\mathrm{mg} / \mathrm{ml}$ 농도로 제조한 MTT 용액 $20 \mu \mathrm{l}$ 를 첨가하여 3시간 배양 한 후 배양액을 제거하고 각 well당 DMSO $200 \mu 1$ 를 가하여 실온에서 30분간 반응 시킨 뒤 ELISA reader로 $550 \mathrm{~nm}$ 에서 흡광도를 측정한 후 (1-시료의 흡광도/대조구의 흡광도) $\times 100$ 에 의하여 생존율을 계산하였다.

\section{Melanin 정량}

멜라닌 양은 Hosoi 등[10]의 방법을 변형하여 사용하였다. $\mathrm{B} 16 \mathrm{~F} 10$ melanoma cell을 6 well에 $5 \times 10^{4}$ cell이 되도록 접종하 여 배양하고, 24 간 뒤 각 well에 도인승기탕 추출물 $(10,50,100$ $\mu \mathrm{g} / \mathrm{ml})$ 와 arbutin $(100 \mu \mathrm{g} / \mathrm{ml})$ 을 48 시간 동안 처리하였다. 처 리 후 phosphate buffered saline (PBS)로 2회 세척한 후 원심 분리하여 세포 침전물을 만들었다. $10 \%$ dimethyl sulfoxide (DMSO)가 첨가된 $1 \mathrm{~N} \mathrm{NaOH}$ 용액을 $150 \mu \mathrm{l}$ 첨가하고 $60^{\circ} \mathrm{C}$ 에 서 1시간 용해하였으며 $405 \mathrm{~nm}$ 에서 흡광도를 측정한 후 실험 군의 멜라닌 양은 대조군의 멜라닌 양에 대한 백분율로 계산 하여 나타내었다.

\section{Tyrosinase 활성 측정}

Tyrosinase 활성 측정은 Choi 등[4]의 방법을 변형하여 측 정하였다. B16F10 melanoma cell을 6 well에 $5 \times 10^{4}$ cello 이 되도 록 접종하여 배양하고, 24 시간 뒤 각 well에 도인승기탕 추출 물 $(10,50,100 \mu \mathrm{g} / \mathrm{ml})$ 과 arbutin $(100 \mu \mathrm{g} / \mathrm{ml})$ 을 48시간 동안 처리한다. 처리 후 PBS로 2회 세척한 후 각 well의 세포에 lysis buffer (1\% triton X-100, 0.1 M Sodium phosphate buffer, 50 $\mathrm{mM}$ PMSF, $\mathrm{pH}$ 6.8)를 가하였다. 얼음 위에서 세포를 파괴시키 고 원심 분리한 후 상층액만 따로 모아 효소용액으로 사용하 였다. L-DOPA를 $2 \mathrm{mg} / \mathrm{ml}$ 농도로 $0.1 \mathrm{M}$ sodium phosphate buffer (pH 6.8)에 녹여 기질을 준비하고 기질 $160 \mu \mathrm{l}$ 에 효소용 액 $40 \mu \mathrm{l}$ 를 가하고 $37^{\circ} \mathrm{C}$ 에서 1 시간 가온하고 생성된 $\mathrm{DOPA}$ chrome의 양을 $490 \mathrm{~nm}$ 에서 측정한 후 (1-시료의 흡광도/대조 구의 흡광도 $\times 100$ 에 의하여 억제율을 계산하였다.

\section{Western blot을 통한 미백 관련 단백질의 발현 측정}

B16F10 melanoma cell를 6 well에 $1 \times 10^{5}$ cells/well에 되도 록 분주하고 24 시간 동안 배양하였다. 배지를 제거한 후 각 cell에 도인승기탕 추출물 $(10,50,100 \mu \mathrm{g} / \mathrm{ml})$ 과 arbutin $(100$ $\mu \mathrm{g} / \mathrm{ml})$ 을 48 시간 동안 처리 후 PBS로 세척하였다. Lysis buffer $100 \mu 1$ 를 첨가하여 세포를 용해시키고 원심분리 하여 $\left(12,000 \mathrm{rpm}, 4^{\circ} \mathrm{C}, 20 \mathrm{~min}\right)$ 세포막 성분들을 제거하였다. 원심 분리하여 얻은 단백질은 BCA (bicinchoninic acid) kit assay로 
정량하였으며, $60 \mu 1$ 의 단백 질을 $10 \%$ 의 SDS-PAGE를 이용하 여 전기 영동 한 후, 항체의 비특이적 결합을 억제시키기 위해 PVDF membrane에 옮긴 다음 $400 \mathrm{mV}$ 에서 2시간 transfer하 였다. Transfer가 끝난 membrane은 5\% skim milk로 1시간 동안 blocking을 한 뒤 1차 antibody tyrosinase, TRP-1, TRP-2, MITF는 3\% skim milk로 1:1000희석하여 사용하고 overnight 한다. Tris-buffered salin and tween 20 (TBST)로 3번 세척한 뒤 2차 antibody anti-goat, anti-mouse, anti-rabbit은 3\% skim milk로 1:1,000 희석하여 1시간 동안 붙이고 TBST로 3 번 세척 한 뒤 enhanced chemiluminescense (ECL) kit (Milipore, Germany)를 이용하여 발현 양상을 측정하였다. Band density 는 gel doc (Amersham Pharmacia, England)을 이용하여 확인 하였다.

\section{통계처리}

결과 통계처리는 SPSS 10.0 을 사용하였으며, 유의차 검증은 분산분석(ANOVA: analysis of variance)을 한 후 $\mathrm{a}=0.05$ 수준 에서 Tukey's HSD test에 의해 유의성을 분석하였다.

\section{결과 및 고찰}

\section{세포 생존 능력 측정 결과}

도인승기탕 추출물의 B16F10 melanoma cell증식에 미치는 영향을 알아보기 위하여 도인승기탕 $70 \%$ 에탄올 추출물 및 물 추출물을 $10,25,50,75,100,250 \mu \mathrm{g} / \mathrm{ml}$ 의 농도로 처리하고 48시간 후에 MTT방법으로 세포의 증식을 관찰한 결과 대조군 의 세포 증식율을 $100 \%$ 로 하였을 때 $250 \mu \mathrm{g} / \mathrm{ml}$ 이하 농도에서 는 독성이 관찰되지 않았다(Fig. 1).

\section{멜라닌 합성 억제 효과}

피부 흑화는 피부에 존재하는 melanocyte가 UV 노출 등의 외부적 환경에 대응하여 melanin의 생성이 증가한다. 멜라닌 생합성으로 인한 색소 침착을 치유하기 위해 멜라닌 생성을 억제하는 hydroquinone, resorcinol 등의 페놀 유도체나, L-ascorbic acid와 그 유도체 및 kojic acid, arbutin, lactic acid, glucosamine, tunicamycin 등이 개발되었으나, 피부 저자극성 이나 안정성에 문제가 있어 극히 제한된 양만 사용되고 있다 $[2,11,20]$. 도인승기탕 추출물의 멜라닌 합성을 확인한 결과, arbutin의 경우 $100 \mathrm{\mu g} / \mathrm{ml}$ 으로 처리하였을 때 멜라닌 합성을 $58 \%$ 저해하였다(Fig. 2). 멜라닌 합성 억제는 물 추출물보다 $70 \%$ 에탄올 추출물을 처리하였을때 우수하였으며 특히 $70 \%$ 에탄올 추출물을 $100 \mathrm{\mu g} / \mathrm{ml}$ 로 처리하였을 때 $55 \%$ 의 멜라닌 합성 억제 효과를 관찰하였다.

Tyrosinase 활성 측정 결과

Tyrosinase의 활성은 melanosome에서 멜라닌이 생성되게

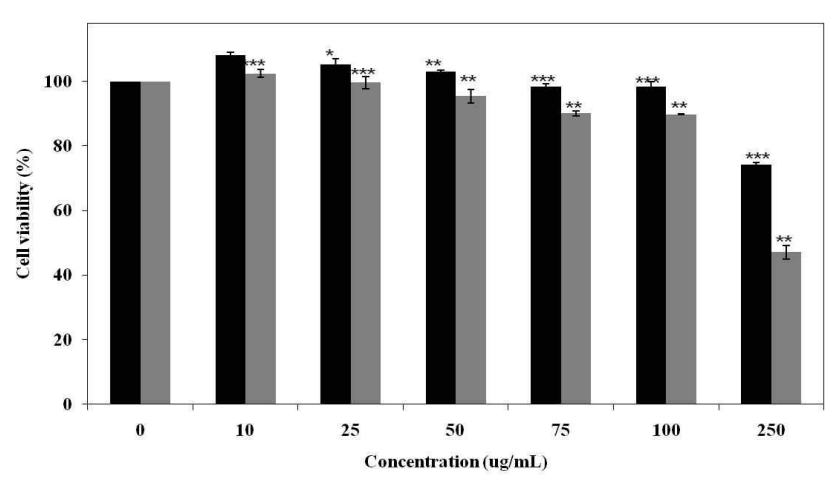

Fig. 1. Cell viability of B16F10 melanoma cells after treatment with Doinseunggitang (Black: water extracts, Gray: 70\% ethanol extracts). The cell were cultured in the presence of various concentration of extracts for $48 \mathrm{hr}$. The viability of the cells was measured by MTT assay. Cells were treated of Doinseunggitang at the indicated concentration for $48 \mathrm{hr}$. The data represent the mean $\pm \mathrm{SD}$ of three separate experiments (Significant as compared to control. $\left.{ }^{*} p<0.05,{ }^{* *} p<0.01,{ }^{* * *} p<0.001\right)$.

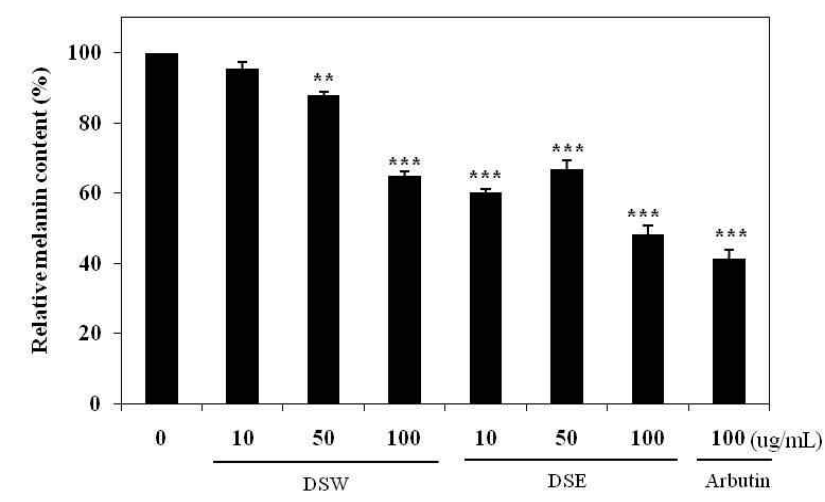

Fig. 2. Effects of $70 \%$ ethanol and water extracts from Doinseunggitang (DS) on melanin synthesis in B16F10 melanoma cells. Cells were absence of Doinseunggitang at the indicated concentration for $48 \mathrm{hr}$. (DSW: Doinseunggitang water extracts 10, 50, $100 \mu \mathrm{g} / \mathrm{ml}$, DSE: Doinseunggitang $70 \%$ ethanol extracts 10, 50, $100 \mu \mathrm{g} / \mathrm{ml}$, Arbutin: $100 \mu \mathrm{g} / \mathrm{ml}$ ). The data represent the mean \pm SD of three separate experiments (Significant as compared to control. ${ }^{*} p<0.05,{ }^{* *} p<0.01,{ }^{* * *} p<0.001$ ).

하는 효소로써 피부노화 촉진 및 색소 침착 등의 문제를 야기 시킬 수 있다[33]. 도인승기탕 추출물 첨가에 따른 tyrosinase 활성 측정 결과 시료의 처리 농도가 높아질수록 tyrosinase 활성이 억제 됨을 확인 할 수 있었다(Fig. 3). 도인승기탕 $70 \%$ 에탄올 추출물 $100 \mathrm{\mu g} / \mathrm{ml}$ 에서 $51 \%$ 의 활성 억제가 관찰 되었 고 물 추출물은 $100 \mathrm{\mu g} / \mathrm{ml}$ 에서 $28 \%$ 의 억제효과가 나타났다. $\mathrm{Kim}$ 등[17]의 연구 결과에 따르면 정공피 추출물 $100 \mathrm{\mu g} / \mathrm{ml}$ 에 서 $6.3 \%$ 억제한 것을 보았을 때 도인승기탕 $70 \%$ 에탄올 추출 물의 tyrosinase 활성 억제능이 우수함을 알 수 있다. 


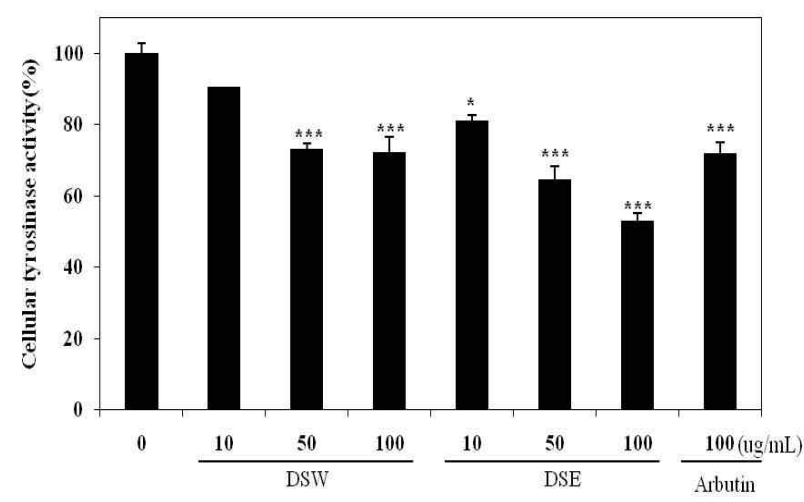

Fig. 3. Effects of $70 \%$ ethanol and water extracts from Doinseunggitang (DS) on tyrosinase activity in B16F10 melanoma cells. Cells were absence of Doinseunggitang at the indicated concentration for $48 \mathrm{hr}$. (DSW: Doinseunggitang water extracts 10, 50, $100 \mu \mathrm{g} / \mathrm{ml}$, DSE: Doinseunggitang 70\% ethanol extracts 10, 50, $100 \mu \mathrm{g} / \mathrm{ml}$, Arbutin: $100 \mu \mathrm{g} / \mathrm{ml}$ ). The data represent the mean $\pm S D$ of three separate experiments (Significant as compared to control. ${ }^{*} p<0.05,{ }^{* *} p<0.01,{ }^{* * *} p<0.001$ ).

\section{Western blot을 이용한 단백질 발현의 측정 결과}

B16F10 melanoma cell은 melanocyte의 세포막에 존재하는 melanocortin 1 receptor (Mc1R)을 통해 멜라닌 합성의 발현 을 유도하는 것으로 알려져 있다[1]. 이 과정에서 microphthalmia transcription factor (MITF)는 핵으로 이동하여 DNA의 tyrosinase, TRP-1, TRP-2의 promotor에 결합하여 각 각의 유전자 발현을 증가시켜 melanogenesis를 유도하는 것 으로 알려져 있다[21]. 이 중 TRP-1과 TRP-2는 tyrosinase related protein 으로 알려져 있는 단백질로서 5,6-dihydroxyindole-2-carboxylic acid (DHICA)를 흑갈색을 나타내는 indole-5,6-quinone-2-carboxylic acid로 산화하는 효소이며 TRP-2는 DCT라고도 하며 DOPA chrome을 DHICA로 이성화 하는 효소로써[12], 이러한 MITF의 억제는 tyrosinase 및 TRP-1, TRP-2의 발현억제를 통하여 melanin 색소 생성을 억 제할 수 있다.

도인승기탕 추출물의 멜라닌 생성 억제 효과를 분석하기 위해 MITF, tyrosinase, TRP-1, TRP-2의 유전자 발현 양상을 관찰하였다(Fig. 4). Tyrosianse에 관한 도인승기탕 추출물은
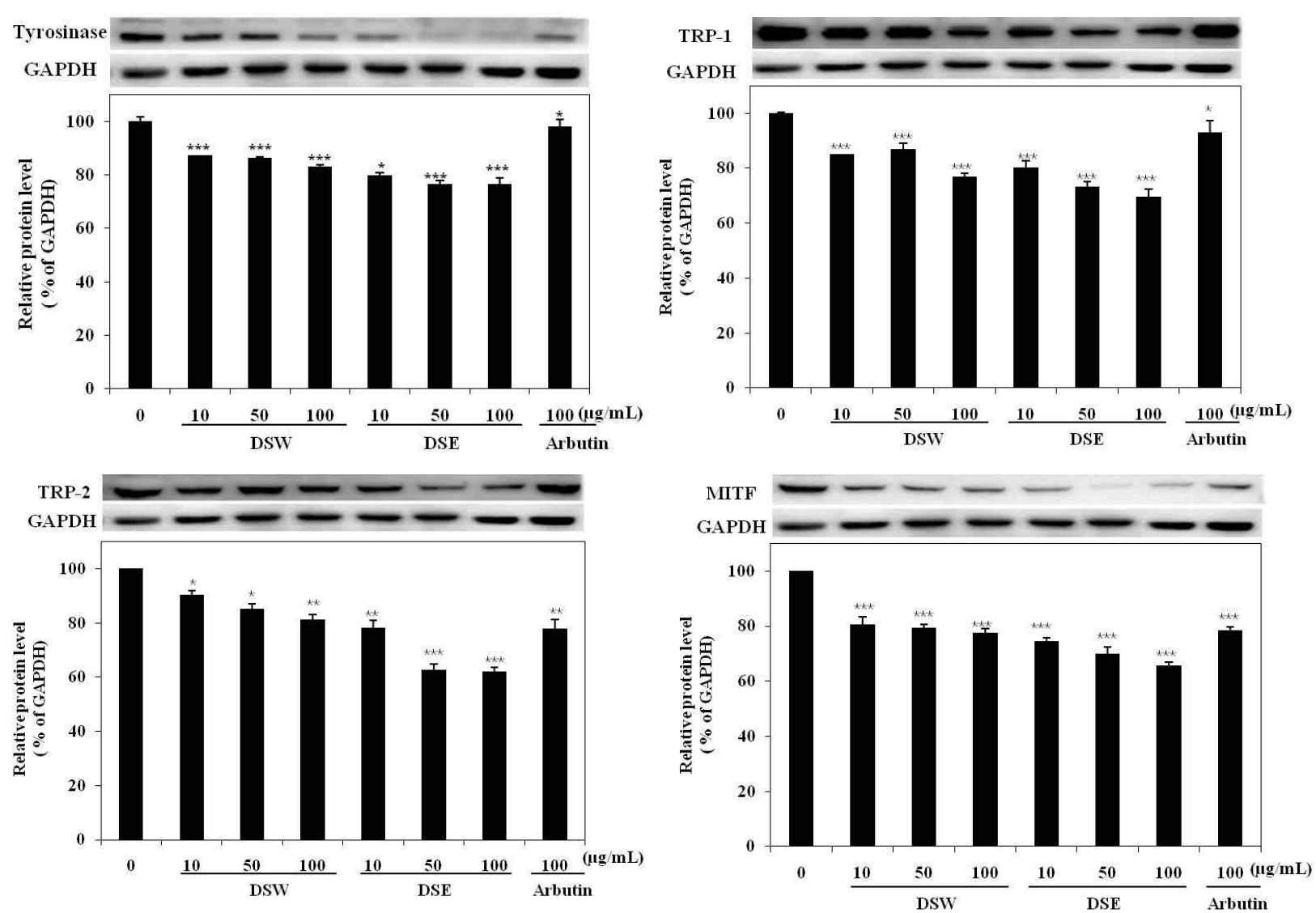

Fig. 4. Effect of $70 \%$ ethanol and water extracts from Doinseunggitang on tyrosinase, TRP-1, TRP-2 and MITF expression in B16F10 melanoma cells. Cells were absence of Doinseunggitang at the indicated concentration for $48 \mathrm{hr}$. (DSW : Doinseunggitang water extracts 10, 50, $100 \mu \mathrm{g} / \mathrm{ml}$, DSE: Doinseunggitang 70\% ethanol extracts 10, 50, $100 \mu \mathrm{g} / \mathrm{ml}$, Arbutin: $100 \mu \mathrm{g} / \mathrm{ml}$ ). The data represent the mean $\pm \mathrm{SD}$ of three separate experiments (Significant as compared to control. ${ }^{*} p<0.05,{ }^{* *} p<0.01,{ }^{* * *} p<0.001$ ). 
물 추출물 및 $70 \%$ 에탄올 추출물 $100 \mu \mathrm{g} / \mathrm{ml}$ 에서 각각 $17 \%$, $24 \%$ 를 저해하였고 arbutin은 $2 \%$ 저해하였다. TRP- 1 은 물 추 출물과 $70 \%$ 에탄올 추출물 $100 \mathrm{\mu g} / \mathrm{ml}$ 에서 각각 $23 \%, 31 \%$ 저해하였으며 arbutin은 $100 \mu \mathrm{g} / \mathrm{ml}$ 에서 7\% 저해율을 관찰할 수 있었다. TRP-2의 발현 양상 역시 TRP-1과 마찬가지로 도인 승기탕 $70 \%$ 에탄올 추출물이 물 추출물과 arbutin보다 저해율 이 우수하였다. 그리고 도인승기탕 추출물의 MTTF 발현에 미치는 효과를 관찰한 결과 물 추출물과 $70 \%$ 에탄올 추출물 $100 \mathrm{\mu g} / \mathrm{ml}$ 에서 각각 $23 \%, 35 \%$ 저해되었고 arbutin은 $100 \mu$ $\mathrm{g} / \mathrm{ml}$ 에서 $22 \%$ 저해되는 것을 관찰 할 수 있었다. 이는 도인승 기탕 추출물이 세포신호전달 경로 중 지속적인 ERK 활성화를 저해함으로써 MITF에 영향을 미쳐 멜라닌 생합성에 직접적으 로 관여하는 효소인 tyrosinase와 TRP-1, TRP-2의 발현을 저해 하는 것으로 생각된다.

Ye 등[37]의 San-bai-tang (백출, 토복령, 작약 1:1:1 혼합추 출물)이 미백관련 단백질 발현 정도를 보면 본 연구 결과와 같은 양상으로 MITF와 tyrosinase의 발현양의 감소 시킴으로 써 TRP-1과 TRP-2도 농도의존적으로 감소하는 것을 관찰하였 다. 김 등[13]의 연구결과에 따르면 이러한 MITF의 억제는 tyrosinase의 발현 억제를 통하여 melanin 색소 생성을 억제할 수 있으며 MITF의 발현이 억제되면 색소생성이 억제될 수 있 다고 보고하였다.

본 연구에서는 멜라닌 생합성에 관여하는 MITF, tyrosinase, TRP-1, TRP-2의 단백 질 발현을 측정한 결과와 멜라 닌 생합성을 확인한 실험 결과와 연관성이 있는 것으로 확인 할 수 있었다.

이와 같은 연구결과를 바탕으로 향후 도인승기탕 추출물이 천연 미백 소재로 활용할 수 있을 것으로 생각된다.

\section{References}

1. Abdel-Malek, Z. A., V. B. Swope, I. Suzuki, D. Harriger, S. T. Boyce, K. Urabe, and V. J. Hearing. 1995. Mitogenic and melanogenic stimulation of normal human melanocytes by melanotropic peptides. Proc. Natl. Acad Sci. USA 92, 1789-1793.

2. Ando, S., O. Ando, Y. Suemoto, and Y. Mishima. 1993. Tyrosinase gene transcription and its control by melanogenic inhibitors. J. Invest. Dermatol. 100, 150S-155S.

3. Carmichael, J., W. G. DeGraff, A. F. Gazdar, J. D. Minna, and J. B. Mitchell. 1987. Evaluation of a tetrazolium based semiautomated colorimetric assay: assessment of chemosensitivity testing. Cancer Res. 47, 936-942.

4. Choi, B. W., B. H. Lee, K. J. Kang, E. S. Lee, and N. H. Lee. 1998. Screening of the tyrosinase inhibitors from marine algae and medicinal plants. Korean J. Pharmacogn. 29, 237-242.

5. Choi, Y. J. and J. Kim. 2006. A study on the propensity to consume oriental herbal cosmetics. J. Soc. Cosmet. Sci. Korea
32, 283-229.

6. Ferguson, C. A. and S. H. Kidson. 1997. The regulation of tyrosinase gene transcription. Pigment Cell Res. 10, 127-138.

7. Ge, R. Y., C. H. Zhou, and Y. C. She. 1983. Influences of stigma croci and Semen persicae on function of ovary-uterus in pseudopregnant rats. J. Tradit. Chin. Med 3, 23-26.

8. Han, Y. S. and E. S. Jung. 2003. A study of correlation between antioxidant activity and whitening effect of plant extracts. Korean J. Aesthetic Society 1, 11-22.

9. Hearing, V. J. and K. Tsukamoto. 1991. Enzymatic control of pigmentation in mammals. FASEB. J. 5, 2902-9

10. Hosoi, J., E. Abe, T. Suda, and T. Kuroki. 1985. Regulation of melanin synthesis of B16 melanoma cells by 1 alpha, 25-dihydroxyvitamin D3 and retinoic acid. Cancer Res. 45, 1474-1478.

11. Imokawa, G. and Y. Mishima. 1982. Loss of melanogenic properties in tyrosinase induced by glucosylation inhibitors within malignant melanoma cells. Cancer Res. 42, 1994-2002.

12. Jimenez, C. C. 2004. Inhibition of melanogenesis in response to oxidative stress: transient down regulation of melanocyte differentiation markers and possible involvement of microphthalmia transcription factor. J. Cell Sci. 114, 2335-2344.

13. Kim, D. H., B. J. An, S. H. Kim, T. S. Park, G. H. Park, and J. H. Son. 2011. Antimelanogenic effect of Ligularia fischeri, Solidago virga-aurea, Aruncus dioicus extracts from ullung island in murine melanoma cells. J. Life Sci. 21, 279-285.

14. Kim, H. M., Y. M. Jang, K.S. Han, D. W. Moon, Y. J. Mun, and W. H. Woo. 2008. Effect of the ethanol extract from Lavandula vera on a-MSH induced melanogenesis. Korean J. Oriental Physiology Pathology 22, 1444-1448.

15. Kim, J. B., S. H. Choi, and K. S. An. 1997. Study on the effects of Taorenchengqitang and its components on blood Stasis model. Korean J. Oriental Physiology Pathology 11, 65-76.

16. Kim, J. H., G. S. Sim, D. H. Lee, G. S. Lee, B. C. Lee, and H. B. Pyo. 2007. New whitening agent from pimpinella brachycarpa. J. Soc. Cosmet. Scientists Korea 33, 203-208.

17. Kim, S. M. and D. Y. Yoo. 2009. The effect of Mibaeksan on melanin synthesis and gene expression. Korean J. Oriental Obstetrics Gynecology 22, 1-18.

18. Kosuge, T., H. Ishida, and M. Ishii. 1985. Studies on active substances in the herbs used for oketsu in chinese medicine. II. On the anticoagulative pronciple in persicae seme. Chem Pharm Bull. 33, 1496-1498.

19. Lee, H. H., S. Bae, and J. E. Chin. 2005. Inhibitory effect of Lithospermum erythrorhizon extracts on melanin biosynthesis. J. Korean Soc. Food Sci. Nutr. 34, 1325-1329.

20. Lin, C. B., L. Babiarz, F. Liebel, P. Roydon, M. Kizoulis, G. J. Gendi menico, D. E. Fisher, and M. Seiberg. 2002. Modulation of microphthal mia-associated transcription factor gene expression alters skin pigmentation. J. Invest. Dermatol. 119, 1330-1340.

21. Lin, J. W., H. M. Chiang, Y. C. Lin, and K. C. Wen. 2008. Natural products with skin-whitening effects. J. Food and Drug Analysis 16, 1-10.

22. Majmudar, G., G. Jacob, Y. Laboy, and L. Fisher. 1998. An in vitro method for screening skin-whitening products. $J$. 
Cosmet. Sci. 49, 361-367.

23. Michikawa, M., K. T. Lim, J. G. McLarnon, and S. U. Kim. 1994. Oxygen radical-induced neurotoxicity in spinal cord neuron cultures. J. Neuro Sci. Res. 37, 62-70.

24. Oh, S. M., Y. J. Mun, and W. H. Woo. 2007. Effects of Rubus coreanus Miquel on the expressions of tyrosinase, TRP-1 and TRP-2 in B16 melanoma cells. Korean J. Oriental Physiology Pathology 21, 1456-1461.

25. Oh, W. K., K. B. Kim, J. Y. Lim, S. K. Lee, Y. D. Kwon, S. R. Yeom, and Y. S. Song. 2009. Effects of Dokhwalkisaeng-tang on melanin synthesis inhibition and gene expression in B16F10 melanoma cells. Korean J. Oriental Physiology Pathology 23, 63-75.

26. Orlow, S. J., R. E. Boissy, D. J. Mortan, and S. Pifkohirst. 1993. Subcellular distribution of tyrosinase and tyrosinase related protein. 1: Implication for melanosumal biogenesis. J. Invest. Dermatol. 100, 55-64.

27. Park, J. S., W. Y. Nam, Y. J. Mun, K. H. Cho, B. W. Jeon, and W. H. Woo. 2000. Effect of Seosiokyongsan on the Melanogenesis of B16 Melanoma Cell Line. Korean J. Oriental Physiology Pathology 14, 160-170.

28. Parvze, S., M. K. Kang, W. S. Chung, C. W. Cho, M. C. Hong, M. K. Shin, and H. S. Bae. 2006. Survey and mechanism of skin depigmenting and lightening agents. Phytother. Res. 20, 921-934.

29. Sakamoto, S., H. Kudo, T. Kawasaki, K. Kuwa, N. Kasahara, S. Sassa, and R. Okamoto. 1988. Effects of a chinese herbal medicine, keishi-bukuryo-gan on the gonadal system of rats. J. Ethnophamacol. 23, 151-158.

30. Seo, E. J., E. S. Hong, M. H. Choi, K. S. Kim, and S. J. Lee. 2010. Antioxidant and skin whitening effects of Ramnus yoshinoi Extracts. Korean J. Food Sci. Technol. 42, 750-754.
31. Shin, J. Y. 2001. Screening of natural products that have activities against skin-aging. Korean J. Food Nutr. 14, 568-572.

32. Tobin, D., A. Quinn, S. Ito, and A. Thody. 1994. The presence of tyrosinase and related protein in human epidermis and theri relationship in melanin type. Pigment Cell Res. 7, 204-209.

33. Tomohiro, I. and F. Yukio. 2005. Hot water extracts from Adzuki beans(vigna angularis) stimulate not only melanogensis in cultured mouse B16 melanoma cells but also pigmentation of hair color in $\mathrm{C} 3 \mathrm{H}$ mice. Biosci. Biotechnol. Biochem 69, 873-882.

34. Veronique, D. M. and B. Friedrich. 1996. Tyrosinase and related proteins in mammalian pigmentation. FEBS Lett. 381, 165-168.

35. Wang, K. H., R. D. Lin, L. H. Feng, H. H. Yen, H. C. Chang, C. Y. Huang, and M. H. Lee. 2006. Cosmetic applications of selected traditional Chinese herbal medicines. J. Ethnopharmacol. 106, 353-359.

36. Yamakoshi, J., F. Otsuka, A. Sano, S. Tokutake, M. Saito, M. Kikuchi, and Y. Kubota. 2003. Litening effect on ultraviolet-induced pigmentation of guinea pig skin by oral administration of a proanthocyanidin-rich extract from grape seeds. Pigment Cell Res. 16, 629-638.

37. Ye, Y., J. H. Chu, H. Wang, H. Xu, G. X. Chou, and A. K. Leung. 2010. Involvement of p38 MAPK signaling pathway in the anti-melanogenic effect of San-bai-tang, a Chinese herbal formula, in B16 cells. J. Ethnopharmacol. 132, 533-535.

38. Zhong, S., W. Yan, S. M. Ahn, Z. Junya, K. Wang, S. Yang, J. H. Yeon, and X. Zhu. 2006. Depigmentation of melanocytes by the treatment of extracts from traditional Chinese herbs: a cell culture assay. Biol. Pharm Bull. 29, 1947-1951.

\section{초록 : 도인승기탕의 B16F10 세포주에서의 멜라닌 생성 및 유전자 발현 억제 효과

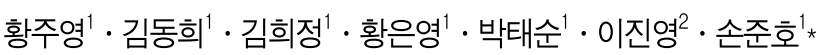 \\ ('한국한방산업진흥원, ${ }^{2}$ 호서대학교 한방화장품과학과)}

본 연구는 B16F10 melanoma 세포를 사용하여 도인승기탕의 $70 \% \mathrm{EtOH}$ 와 물 추출물의 멜라닌 생합성, tyrosinase 활성, western blotting으로 측정하였다. 도인승기탕 추출물은 농도 의존적으로 멜라닌 생합성과 tyrosinase활성을 저해하였다. 그 결과 도인승기탕 $70 \%$ 에탄올 추출물이 멜라닌 합성을 $40 \%$, tyrosinase는 $51 \%$ 저 해효과를 나타내었다. Western blot을 이용하여 B16F10 melanoma 세포 내에 tyrosinase, TRP-1, TRP-2, MITF의 발현을 억제하는 효과를 관찰하였다. 이상의 결과에 따라 도인승기탕의 $70 \%$ 에탄올 추출물은 미백 소재로서 가 능성을 가지는 것으로 나타났다. 